\title{
Rust and dust: materiality and the feel of memory at Camp des Milles
}

\begin{tabular}{|c|l|}
\hline Journal: & Journal Of Material Culture \\
\hline Manuscript ID & MCU-17-0035.R1 \\
\hline Manuscript Type: & Original Article \\
\hline Keywords: & $\begin{array}{l}\text { memory, materiality, sensory ethnography, minor gesture, lieux de } \\
\text { mémoire }\end{array}$ \\
\hline Abstract: & $\begin{array}{l}\text { In this article we explore the potential of state-sponsored memory sites to } \\
\text { engender multi-chronological and sensorial accounts of the past, and } \\
\text { create new meanings for visitors in doing so. We do so through recounting } \\
\text { first hand experiences of the Camp des Milles, a Second World War } \\
\text { internment and deportation camp in the south of France, near Aix-en- } \\
\text { Provence. Inaugurated in 2012, in addition to being an official lieux de } \\
\text { mémoire, Camp des Milles also has an explicit pedagogical function in } \\
\text { seeking to raise awareness of racism and anti-semitism, and how to } \\
\text { combat it. The article hinges on oral accounts of a visit to the site, and } \\
\text { accompanying photographs, which together provide an empirical starting } \\
\text { point for a series of linked concepts that frame our arguments. Beginning } \\
\text { with Manning's (2015) notion of the 'minor gesture', we build on recent } \\
\text { work on more-than-representational approaches to memory and place, and } \\
\text { draw in explorations of materiality and industrial ruins. Overall, we call for } \\
\text { a more subtle and atmospheric understanding of state-sponsored memory } \\
\text { sites, one that attends to the emergent experiences people have in them, } \\
\text { that can allows us to understand their affective impact much more clearly, } \\
\text { and thus their potential to promulgate and intensify their messages. }\end{array}$ \\
\hline
\end{tabular}

\section{SCHOLARONE}

Manuscripts 


\section{Rust and dust: materiality and the feel of memory at Camp des Milles}

Shanti Sumartojo, Matthew Graves

\section{Introduction}

In this article, we attend to the experience of one state-sponsored memory site, exploring how it gives rise to affective intensities that emerge through combinations of its spatial environments and the sensory perceptions and personal thoughts and memories of visitors who encountered them. We approach the site by way of embodied and subjective experiences that augment and exceed the narrative and representational understandings of museum and memorial sites. Instead, our morethan-representational approach opens the possibility of perceiving and making sense of memorial sites in much richer and more intimate ways, revealing how such sites work to stimulate visitors' senses and invoke their memories to craft new ways of understanding the past.

We ask how memory sites work on us and what potential for alternative and complex readings of the past may be possible. To do so, we link a series of concepts to help make sense of the intense and affecting entanglement of the built environment, materiality, memory, history and sensory perception in such places. Our approach highlights the past not as tidy or linear, like an archive to be accessed, recalled or considered in direct relationship to the present, 'available for instant replay in the mind or recountable as seamless, demystifying narratives' (Edensor 2005a: 845). Instead, we will discuss the experiential, dynamic and multi- or 
achronological potential of the past, as it erupts into, pierces and frames the present, and is called to the foreground of attention by the sensory perceptions and material encounters that occur as we move through our surroundings. As such, these emergent and sometimes disruptive intrusions of the past become part of how we perceive and come to understand our environments, a rich resource not only to make meaning, but to intensify and deepen it, to help it stick. This occurs as the more-than-representational, affective and atmospheric aspects of space bubble up by way of apprehensions of smell, light, sound and texture in unpredictable but powerful ways. As Crouch (2015: 177) calls for, in this article we attend to the 'energies, feelings, affects and emotions wrapped up or available in our encounters with heritage' seeking to peer into the intimate tangle of feeling, place and the past. Our intention, however, is not so much to unpick this skein as to begin to account for how it can make the experiences of such sites meaningful, powerful and lasting.

Such an approach is on the increase at the intersection of memory and cultural geography, and new work that explores how memory might contribute to or conjure spatial atmospheres ripe with affective intensities is emerging rapidly. This includes calls for memory to be more regularly attended to in non- and more-thanrepresentational approaches (Jones 2011, Jones and Garde-Hansen 2012, Drozdzewski et al 2016a, 2016b), with new research in empirical settings in museums (Waterton and Dittmer 2014, Witcomb 2013), memorials and commemorative ceremonies (Sumartojo 2015, 2016) and everyday settings where memory might linger or unexpectedly reimpose itself on our consciousness (Muzaini 2015, Halilovich 2016, Edensor 2005a, 2005b). In this work, a subtle and atmospheric 
rendering of memory sites, one that attends to the emergent experiences people have in them, allows us to understand their affective impact much more clearly, and thus their potential to promulgate and intensify their messages. It also connects to scholarship in memory studies on the 'intersections of sensation, experience, and meaning that arise through our interactions with material forms' (Freeman et al 2016: 4). This orientation to materials and the senses recognises that 'we rarely remember through ideas only, but rather through our encounters with things and through embodiments and disembodiments collected in material traces and objects'(Freeman et al 2016: 3-4). With this in mind, we begin by describing our research site and then present two accounts of experiences of the site, through which we then trace a number of conceptual threads.

\section{The Camp des Milles}

Camp des Milles is a French national memory site in the village of Les Milles, on the southern outskirts of the city of Aix-en-Provence. It was a tile factory until 1939, when it was transformed into an internment camp for 'enemy aliens' (including German anti-fascists who had sought refuge in France). Following the Armistice of 22 June 1940, it became a holding and transition camp for foreign nationals and other 'undesirables' seeking to leave the Vichy 'free zone. The lengthy bureaucratic processes meant that some people were detained here for up to two years, but in this early period, it was still possible to leave France via processing at the camp. By 1942 , however, its purpose had changed to the deportation of Jewish people, who were arrested and detained by French officials, and sent by rail to Auschwitz via 
Drancy. Despite the deportation of more than 2,000 people, including over a hundred children and adolescents, after the war this history was voluntarily forgotten and by 1947 it was a tile factory again, an industry that continued until the early 1990s. After a decade-long fundraising and design process, the memorial site was inaugurated in 2012 in a national ceremony led by Prime Minister Jean-Marc Ayrault, and officially opened to the public. It is the only Second World War internment camp preserved in France. It enjoys official status as a national 'haut lieu de mémoire Français' and is a UNESCO Chair, in recognition of its pedagogical role at an international level (Camp des Milles, n.d.).

Camp des Milles seeks to create 'a link between the past and the present' in three distinct sections dedicated to 'knowledge, emotion and reflection' (Camp des Milles: 32). These distinct spatial zones are explained in a short introductory film that begins most visits. The first, historical section presents the local, national and international context of the site, provides a timeline of the events preceding the war and also displays artworks produced by internees alongside testimonies of survivors - we have written about aspects of this area elsewhere (authors, under review). The second section is designed as a memorial, where visitors have 'access to the traces left by the prisoners' (Camp des Milles: 32). This takes the form of a walking route through the different rooms and levels of the building itself, with explanatory text showing the remaining graffiti on the walls, the use of different spaces and the conditions that internees endured. The final section is dedicated to 'reflection', and invites attendees to consider personal and collective responsibility for resisting violence and discrimination. In text and some photographs of individuals, it gives 
examples of forms of resistance to official discriminatory policies and discusses how such violence can become normalized and ultimately lead to genocide. Here, in addition to its role as a site-specific museum and memorial, Camp des Milles also has an explicit pedagogical mission beyond the chronology of the Second World War and the Shoah, using the site's history to educate groups of schoolchildren and local officials about racism, anti-Semitism and earlier and later genocides in Armenia and Rwanda. This is intended to help build understanding of contemporary immigrant groups and guard against the repetition of large-scale racial or religious discrimination and violence.

In this article, we focus on the experience of the middle section of the museum, the passage through the partially restored factory that places visitors in an atmospheric spatial environment and invites them to consider first-hand the sensory and material experiences of internees. It centres around the large room that visitors encounter at the beginning of this section. The photographs and accompanying short first hand description from Shanti's fieldnotes make an introduction to the space.

\section{Account 1}

As I step through the glass doors into the large, open space, the first thing I notice is the cold. The room is unheated and the sunlight slicing in through the roof windows does nothing to warm my chilly body, although the sun is bright and high. The light plays along the walls, casting shadows of beams and hanging fixtures that crosscut their mottled and pocked surfaces. The objects and equipment dotted around the 
room - vaguely industrial, old-looking but difficult to actually place in time-appear to have been arranged as a careful tableau, their materiality of iron and wood a complement to the dusty ochres, browns and sandy tones of the walls and floor.

[INSERT IMAGES 1-4]

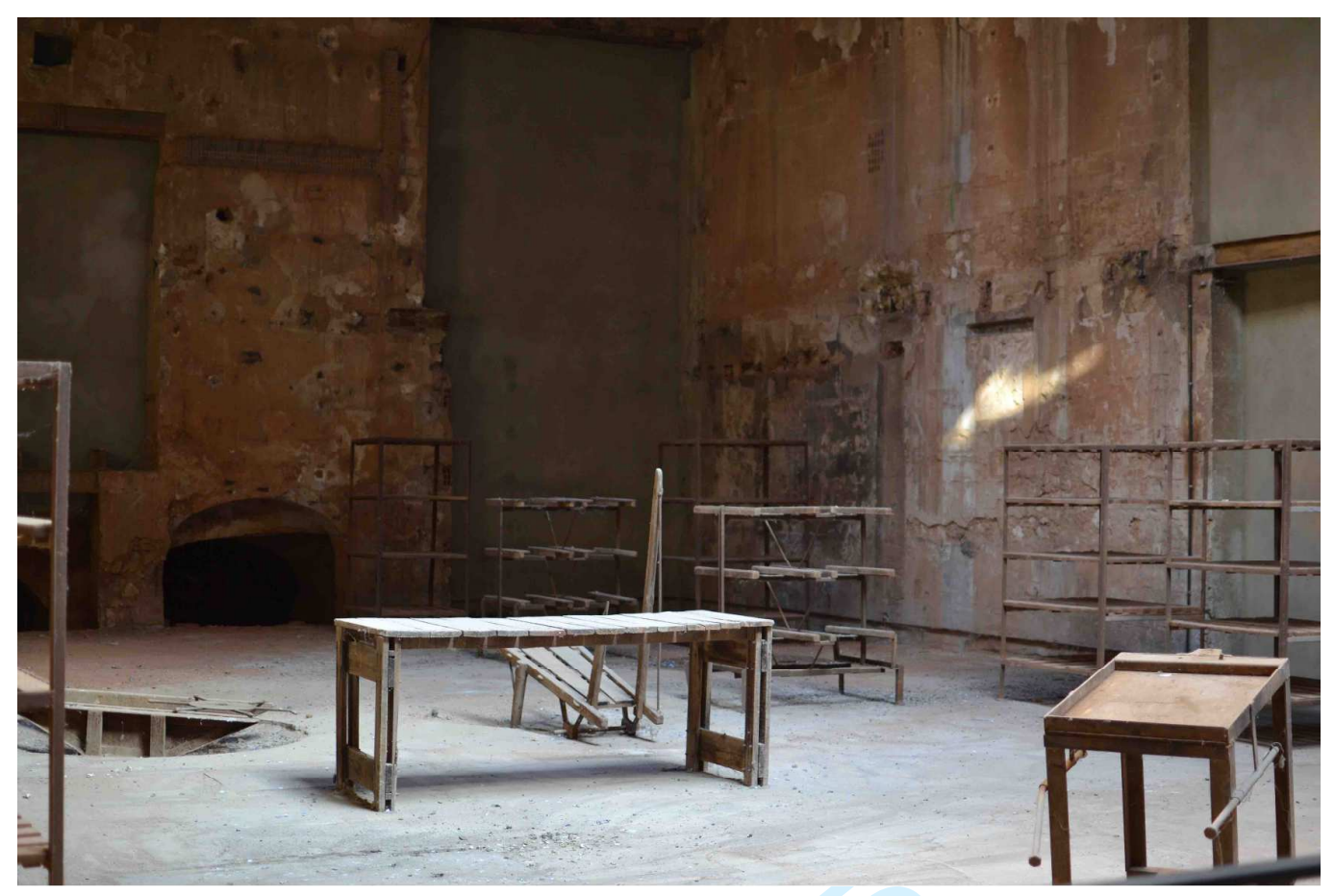



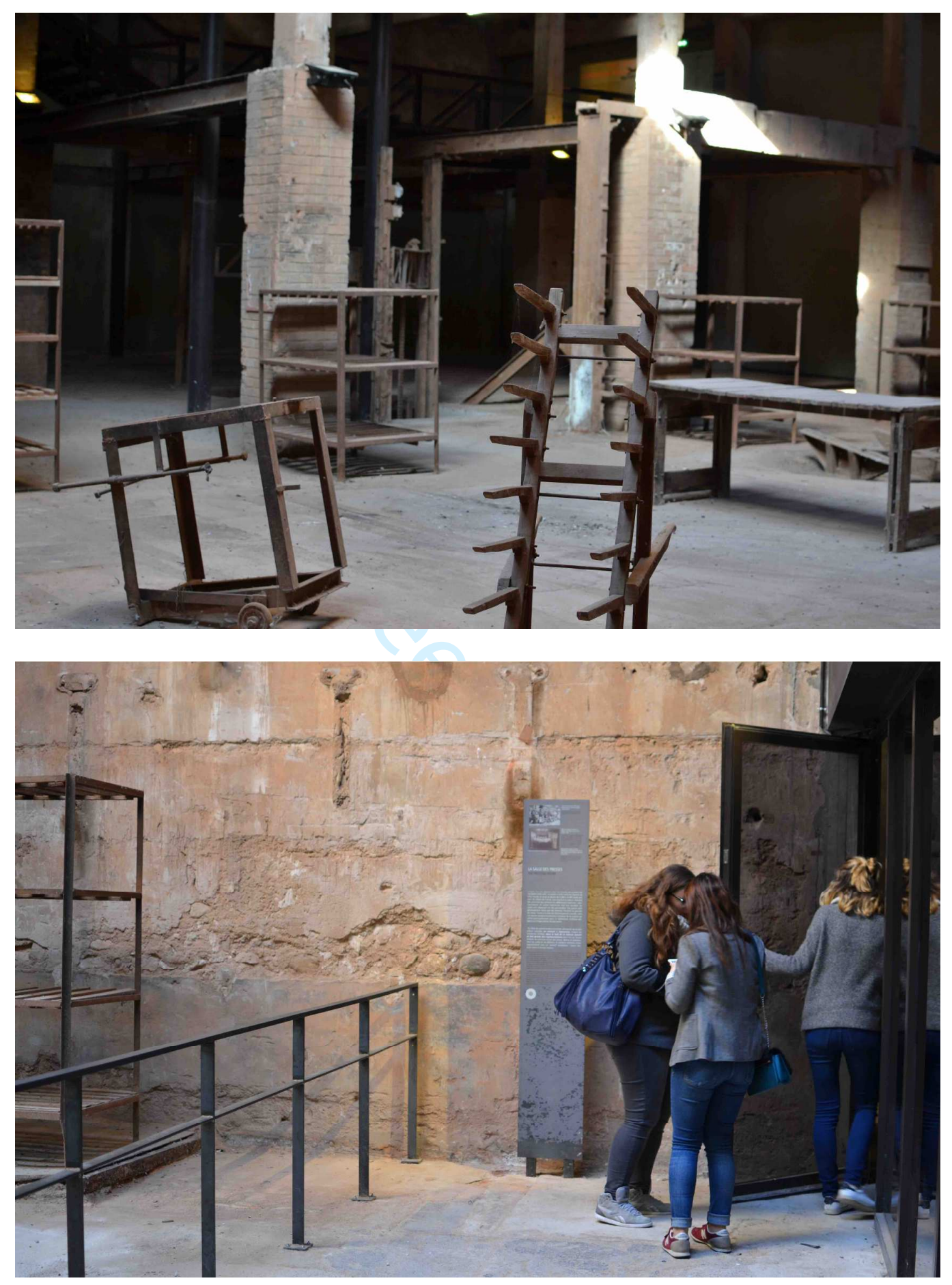


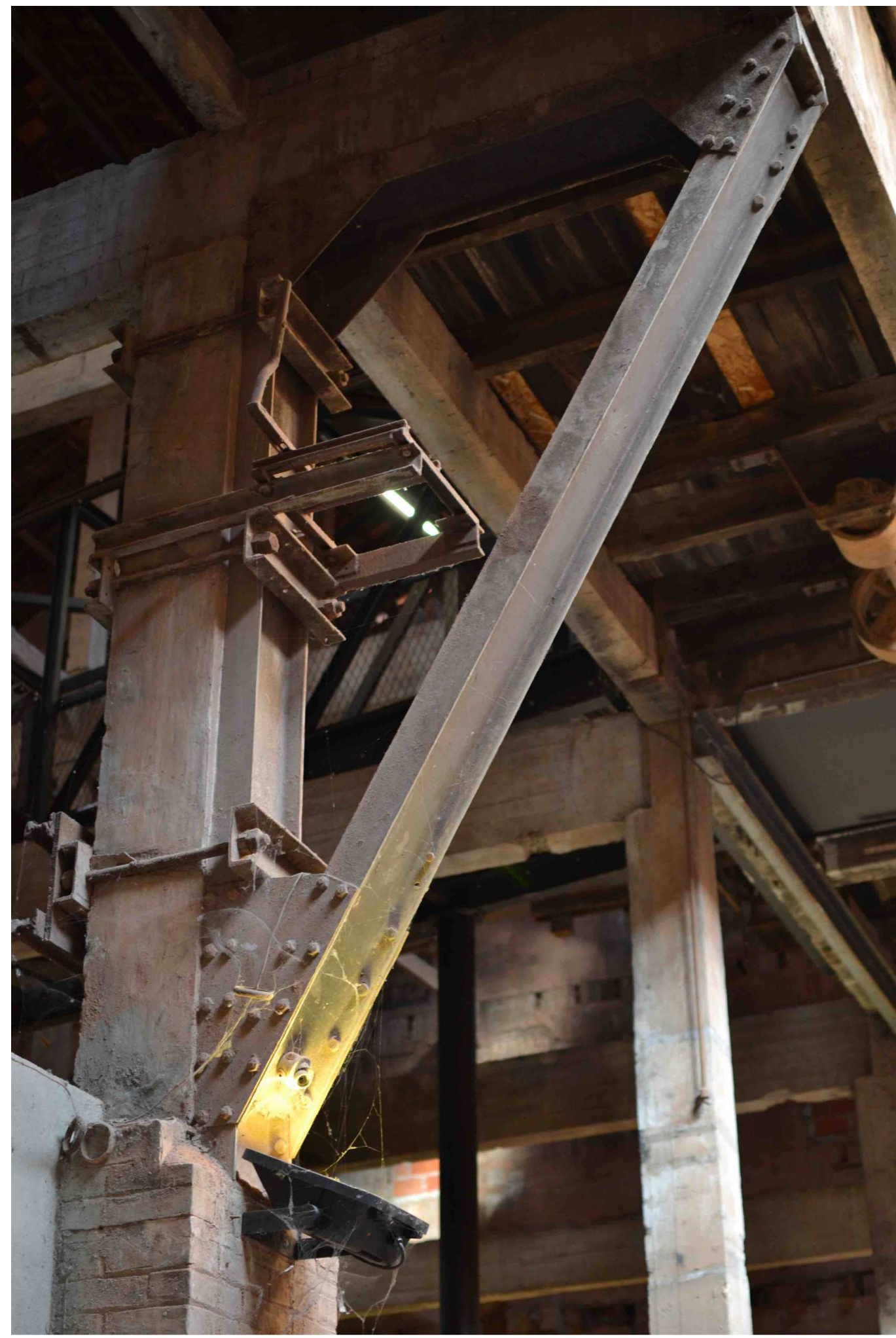

Figures 1-4: The main room in the memorial section of Camp des Milles. Photos:

Shanti Sumartojo. 
In the atmospheric environment of this room, history and memory were thickened through the sensory quality of the light, the cold, stinging touch of outside air, the materiality of the built structures, the tones and patina of the walls and the dust, feathers and pigeon droppings accumulated on the floors. The passage of time was perceived, understood and reinforced in particular ways through the author's material surrounds and sensory perceptions. This recalls Gillis' (1994: 5) comment that 'memories are not things we think about, but things we think with' and begins to show how memory feels in such a site, treating it as an imaginative, affective category of experience, a result in part of how we are attuned to our surroundings. In this sense, time has rendered place as affective in particular ways, which as we will show, is not chronological, but mixes and melds different moments of experience.

The study we undertook at Camp des Milles was a digital sensory ethnography (Pink 2015) that sought to understand how our research participants experienced the site by reaching beyond what they might simply describe using more conventional methods. Instead, we sought to account for their sensory perceptions and embodied responses, which included their own recollections of the past. Conducted in the autumn of 2016, it was focused towards 'sensory perception and forms of embodied knowing that are not necessarily understood through cognitive categories' (Pink et al 2016). We invited nine people - two men and seven women - to visit the site with us, where we also made our own notes and photographs. Apart from one of the authors, all the participants were either local to the area or had lived there for many 
years. We all took photographs on our smartphones of the aspects that most drew our attention. Because one aspect of the project was focused on digital technology, we requested that participants try to represent some of these elements of the site in their photographs, but otherwise left the choice of subject matter open.

A few days later, we video interviewed the participants individually, asking them to explain why they took each photograph and the thoughts, feelings and sensory perceptions they recalled from taking them. ${ }^{1}$ In many of these interviews, stories from participants' own pasts were used to interpret or frame their experience of the site and their choice to photograph what they thought were its most striking elements. Some participants had family histories that meant they related strongly to the experiences of internees; others appeared to relate to physical aspects of survivor testimonies in intimate ways; yet others felt connected because of their local, regional identification. In all of these cases, the ways they experienced, perceived and understood the site mixed the representational and more-thanrepresentational. In the analysis below, we focus on one account that exemplified most strongly this mix, as well as the layering of time, the senses and the spatial experience that other participants also reported. We also include an accompanying digital image, made by participant Ben, a man in his mid-twenties who grew up in the local area. We use his account and photograph to investigate three aspects of the experience of the site that was also present in other participants' accounts, but that he articulated most clearly.

\footnotetext{
${ }^{1}$ The study received RMIT university human ethics approval.
} 
As a way into this material, we begin by considering the movement of his hands as he explained his photograph and the room it depicted, taking a starting cue from Manning's (2016) notion of the 'minor gesture'. We then connect this to recent work on memory and the sensorial, in an attempt to make sense of the multichronological nature of Ben's account and its entanglement in a specific sensory encounter. Finally, we grapple with the materiality at the heart of his experience, attending to the perception of industrial decay to which he was particularly attuned and that triggered his memory and imagination. We conclude with some comments on how our approach can shed light on the politics and potential of state-sponsored memory sites in general. First, however, we turn to Ben's photograph and description of his reaction to the room that he related when we asked him to explain the choice and subject matter of his panoramic photograph.

\section{Account 2}

[INSERT FIGURE 5]

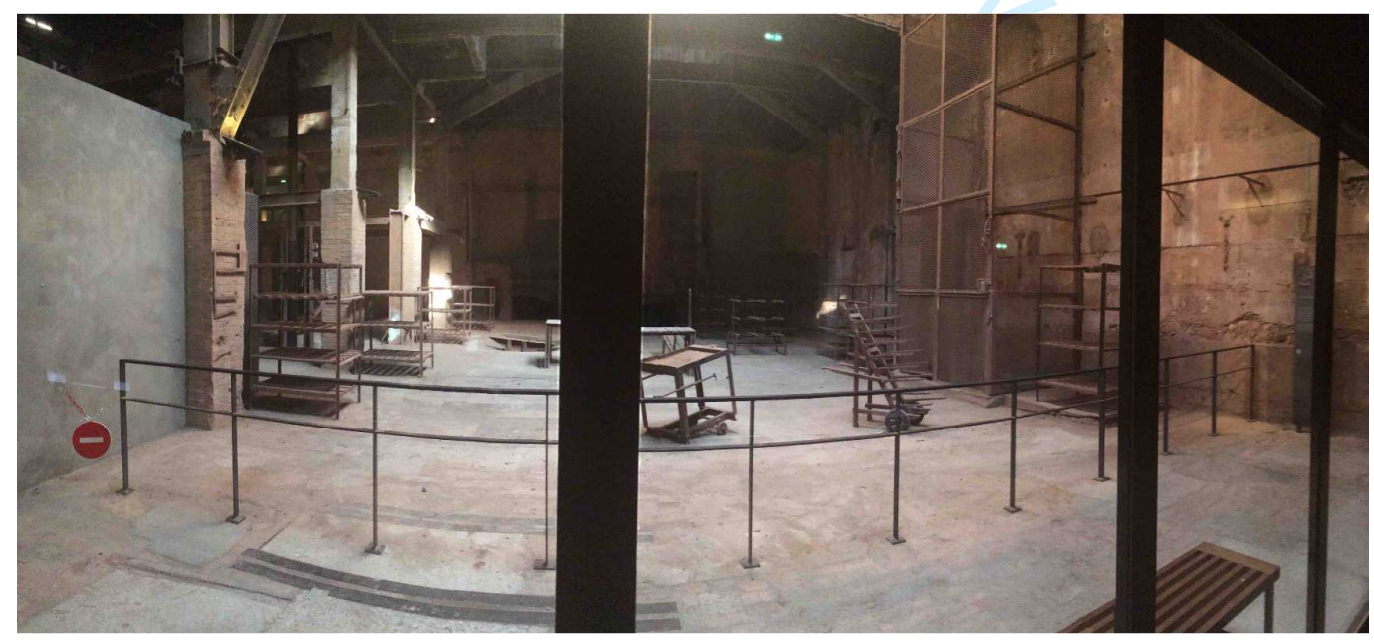

Figure 5: B's panorama image of the same room. 
My father used to be a blacksmith...I always had the smell of rust, it's something I like because sometimes I helped him working on it when I was younger, so to me it's something that connotes with something positive. But in this context it's, yeah, I don't think I could bear being in so much rust and dust because it feels very dry and it dries up your nose and your fingers, fingertips and everything. So, to me there are the two notions that clashed in my mind...I know how dirty it can make you, the rust, and I just understood that people in this environment, they didn't have any choice but to be dirty all the time, and it just made me realise how dire the conditions were for people being imprisoned there...It must have made people feel so dirty...it's really hard to fathom...That was one of the issues in my father's workshop... we had to open one door here and another door there so that the air would go through and get us rid of the cloud of either smoke or dust or whatever. So when I looked at that [room], I was like, that must have been pretty tough, you know.

\section{The minor gesture and atmospheric attunement}

Ben's account turns on a small manual gesture, a rubbing of his fingers against his thumb that he used to demonstrate how he imagined the dusty air in the room that he photographed (Figure 5) and described above. In the video interview his hands added a haptic, gestural element to his description of the scent of rust in the air and the drying effect of dust (Figure 6). Apparently unwittingly, his fluttering fingers demonstrated a sensory mix of the smell in the room, the recollection of the feel of dust (whether he actually felt this as he stood in the room, or if it was a recollection 
of his childhood, was not clear) and the raspy, dry sensation that experience had taught him could be produced by exposure to such particles.

\section{[INSERT FIGURE 6]}

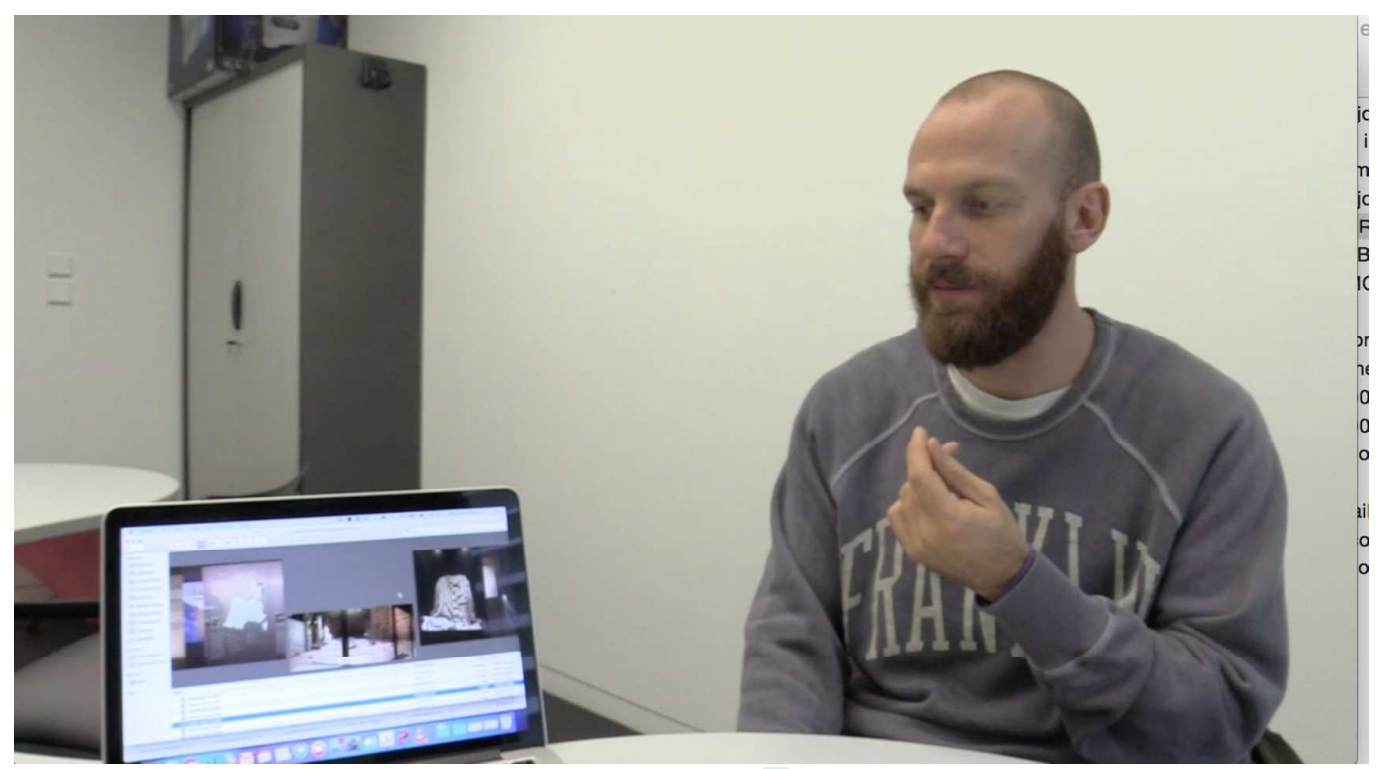

Figure 6: A still from Shanti's interview with Ben, when he described the smell and feel of the dust he sensed in the room in his photograph by rubbing his fingers and thumb together. He is glancing at the photograph of the room on the computer screen.

The movement of Ben's hand finds a conceptual reflection in Manning's notion of the 'minor gesture'. Drawing on her work with Massumi, Manning explores the potential of the 'minor key' that 'does not have the full force of a pre-existing status, or a given structure' (2016: 2), but that can unmoor or problematise the major structures that it courses through. As she describes it, the minor has a sort of freedom and unpredictability that although 'narrated as secondary' has the scope to 
'initiate the subtle shifts that [create] the conditions for...change' (1). It therefore holds the political potential to unsettle, divert, or enable new ways of being and doing. To explain how this might work, she uses the trope of the 'minor gesture' that is 'everywhere, all the time' (2), 'the force that makes the lines tremble that compose the everyday' (7). The minor gesture can thus redirect us because: 'It moves the nonconscious towards the conscious, makes felt the unsayable in the said, brings into resonance field effects otherwise backgrounded in experience' (7). Although Manning uses the word gesture to signal a range of actions far beyond the manual, it allows us an analytical frame for the movement of Ben's hands, which appeared to occur unconsciously as a way to tell his story. Indeed, it only emerged in the video interview encounter, and could have passed unnoticed if not for the video trace of this motion (Pink 2007).

Connecting Manning's concept to Ben's physical 'minor gesture' prises open ways of thinking about memory sites that move far beyond official narrative, archival capture or even personal engagement with the past. It allows us to see the emergent possibilities of experience, to conceptualise such places beyond the historical narratives that might frame them. It can begin to explain how such a room might engender experiences or events with a resonance that shimmers in time and space, that emerges and dissipates, that 'punctuates the in-act, leading the event elsewhere than toward the governant fixity of the major' (Manning 2016: 7), the major in this case being the state-sponsored history represented at Camp des Milles. In Ben's case, the 'minor' was part of a personal memory that made the experience 
of the space more intense and connected him, through his own past, to the experiences of others in the same space, at least as he imagined them.

The smell and feel of the site also placed him in the memorial's past as an internment camp (by way of his own less distant childhood) as he imagined the dire conditions and inescapable grime that internees endured. The materiality of the site thus worked to engender a form of empathy with people who had been there before him that imbricated his own experiential memory with how he imagined the experiences of others. As such, it went beyond simply thinking about what the site could have been like to feeling it in both a corporeal and affective sense. In this way, the minor gesture can take us beneath the official narrative, whilst still responding to it, bringing to the fore an everyday memory that intensified Ben's experience. This is worth attending to because it allows us to think about the politics of such as site in ways that move beyond official intentions and state-sponsored narratives. Instead, it opens up ways of understanding lieux de mémoire, sites often understood as closely linked to official ways of representing the past (Nora 1989), as much more diverse, personal, emergent and experiential, recalling but moving beyond Connerton's appeal to attend to the embodied memory implicit in collective commemorative ritual (1989).

Such a site can also be imbued with 'atmospheric' qualities that visitors identify even if they cannot always precisely describe them. Indeed, Stewart (2007) argues that these powerful combinations are pulled into being by way of attunement to our surroundings and their affordances. In the case of this study, attunement was an 
active process, foreshadowed by anticipation (Edensor 2012, Sumartojo 2016) as participants imagined and prepared to visit Camp des Milles. In asking participants to make note of and photograph those aspects of the site that most attracted their attention, the research task encouraged them to attune to their surroundings. Attunement emerges here as closely related to how we might conceptualise places as imbued with particular atmospheres, something that emerges clearly in B's account. Edensor and Sumartojo (2015) argue that atmosphere does not simply sweep people up, hapless or mute, but that instead we are co-constituents of the feel of place, 'perceiving subjects' (Anderson 2009) complicit in blending the material and immaterial through our spatialised experiences. In attending to the sensory and affective aspects of our surroundings, 'we perceive atmosphere through our emotional sensibility - a form of perception that works in credibly quickly' (Zumthor 2006: 13). Spatial attunement here is manifest as affective intensities suffuse and course through our bodies, by way of how we feel, and as we will show, what we may remember. McCormack (2008: 413) similarly describes spatial atmosphere as a 'quality of environmental immersion that registers in and through sensing bodies whilst also remaining diffuse, in the air, ethereal'; as such it emerges and exists in the combinations of people with places and their representational and more-than-representational qualities. Attuning to space in this way foregrounds the senses, and their subtle but insistent and vital contribution to how we understand our surroundings. As we discuss next, this is entangled with personal memory, revealing the past as dynamic and contingent, even in the face of official narrative.

\section{Memory and the senses}


Ben's account was triggered in large part by the smell and feel of the air in the room to which he became attuned in part by the research exercise of taking a photograph. It also emerged as a result of the subsequent discussion with the author about the image and the experience it represented. As discussed above, the memory as Ben experienced and discussed it came together in the motion of his rubbing fingers. This gesture calls us to attend to the experience of memory as it occurs, and the importance of the senses in both the moment of memory and in the recounting of it. Indeed, recent work on memory and experience (Sumartojo 2015, Drozdzewski 2014, Muzaini 2015, Sturken 2016) foreground the role of the experiencing body at memory sites, and the way it can compel us to attend to 'everyday' concerns alongside official or discursive aspects of such places: 'their sensory cues provoke remembrance; they install pauses and digressions in our normative thought processes; and they transport us, however momentarily, to different times and different places' (Drozdzewski et al 2016a: 447). The accounts above show how the sound, smell, look, taste and feel of memory sites are a vital aspect of how we encounter and make sense of them. It follows that these sensory aspects can heighten or diminish the narrative content, making it feel more (or less) personal, proximate and relevant. In this vein, Sather-Wagstaff (2017: 18) encourages us to 'make polysense' of memory, an approached centred on 'the dynamic relationship between the senses, feeling, emotion, cognition and memory as continually in process.' She urges attention to the purposeful use of 'affective, polysensory modes of encounter' (2017: 19) at heritage sites, and although she focuses on objects and 
material culture, the same could be said of rooms and other spaces with distinctive lighting, smells, sounds and temperatures.

The capacity of our surroundings, and notably the built environment, to trigger memory in unexpected ways and cause it to erupt into the present, is also a feature of Muzaini's (2015) recent study of forgetting amongst war veterans. He focuses on the involuntary and unexpected return of those memories, prompted in part by material and sensory surroundings. He points out the importance of the 'manipulation of the material' (2015: 104) in shaping how and what groups remember or purposefully seek to forget, including through museums and monumental structures. However, visitors complicate this narrative with their own experiences and memories that can spring unbidden to their attention, at times because of 'encounters with the material' that can 'incite even what has been consciously relegated to history' (Muzaini 2015: 105). For example, a drive past a school that had been used by Japanese occupying soldiers for the interrogation and murder of civilians unexpectedly invoked unwanted and distressing memories in one of his research participants. The material presence of the school itself was enough to spark memories that shaped how the buildings were then perceived in the present. Muzaini builds on Edensor's (2005a: 837) work on industrial ruins (discussed in more detail in the next section) that draws together material surroundings with the working of 'involuntary memories', prompted by sensory experience:

Involuntary memories, in contrast to the conscious use, transmission, and representation of the past, are unpredictable and contingent, and, 
given that they are enmeshed in sensation and vague intimations of previous atmospheres, they are slippery to describe and represent. Not deliberately sought, involuntary memories come upon us, rekindling the past through unexpected confrontations with sounds, 'atmospheres', and particularly smells - largely nonvisual sensual experiences.

This can be extended to include memorials or state-sponsored memory sites such as Camp des Milles that tell a story of the past in very particular ways. It helps to account for Ben's story about his childhood memory, a recollection that was prompted by the look, smell and feel of his material surroundings, but that was out of step with his empathy for the suffering of internees. A notable aspect of this account was how it moved through different periods of time, drawing together his own spatial encounter with the room, with his childhood memory of his father's workshop, with how he imagined internees' experiences during their detention. His account jumped around, mixing and layering his own immediate experiences with his imagination, memories of different times of his life and diverse relationalities with others as he remembered or imagined himself in the past. As he explained, this set up dissonance, as with 'the two notions that clashed in my mind': the smell of rust prompting both a positive memory of helping his father as a child, and invoking the inescapable grime and dirt, the 'dire conditions' that he imagined internees must have endured. This dissonance is implicit in the site itself, where the narrative of internment is privileged, despite the blend of incarceration and industrial heritage in the material environment of the site, the same environment that evoked Ben's complex response. The dust that he remarks on is a result of the industrial processes 
in the site that ended in the 1990s, activities which largely (but not completely) erased its wartime use. In a sense, it was as if time was frozen in 1942 and then flowed inconsequentially afterward, even though the material remains of this more recent period penetrated the nostrils and rubbed onto visitors' fingertips, making it difficult to ignore sensorially.

Ben did not know what he would encounter at Camp des Milles, what he would photograph, or what that activity would make possible. For him, memory was not a disembodied process of recall or remembering, but rather an emergent, embodied and emplaced way of making sense of the world, an aspect of ongoing everyday life that was not somehow separate from it in time or space (Ingold 2011, Pink 2015). This helps to explain why Ben's encounter with the memory site, precisely because it was emergent and experiential, did not adhere to a linear or predictable chronology. His account showed how his own memory was part of how a state-sponsored memory site was made meaningful, as he mixed and grafted it together with sensory experience past and present, including those of others as he imagined them. Put another way, 'Memory renders our relationships with others, timespace, information and materiality complex, multidimensional and non-linear' (Jones 2011: 877). The sensory aspects of memory, revealed through the 'minor gesture' of Ben's 'feeling' the air and the attention to it that the gesture represented, disrupted time in a way that built a rich, engaged experience of the site, one that moved away from the historical events it represented and pulled the place directly into his own subjectivity. 


\section{Dust and materiality}

The final aspect we discuss here is the particular materiality of the room where Ben and Shanti took photographs, a spatial quality that Muzaini (2015) and Edensor (2005b) both address. As the images (Figures 1-5) and descriptions that begin this article hint, the setting of Camp des Milles is remarkable. The industrial implements and fittings that have been retained attest to its former purpose as a tile factory, whilst the traces left by internees speak to an interruption of this purpose, when its kilns, rooms and corridors were used to house thousands of people. The middle, memorial section of the museum is dusty, dirty and exposed, with feathers and bird droppings thick in some areas, walls unpainted, windows covered with grime and no heating or cooling in the most open parts of the building. The rusting fittings, walls streaked with damp and derelict interiors nevertheless combine in a sensorially rich environment, with a very particular aesthetic that is beautiful and haunting. This effect is heightened by the visitors knowledge that many people held at the Camp des Milles were later murdered at concentration camps.

In their call for an orientation to materiality, Coole and Frost (2010: 1) make the case that 'we live our lives surrounded by, immersed in matter. We are ourselves composed of matter. We experience its restlessness and intransigence even as we reconfigure and consume it' even as we take it for granted (see also Bennett 2010). This rendering of matter as all around us, and as something we might absorb into our bodies, can frame Ben's description of the 'smell of rust and dust', the drying of his nose and fingertips, and the smoky, dusty interior of his father's smithy that 
required airing out. As he rubbed his fingers together, he appeared to feel the imagined particles in the air that entered his nostrils or settled on his skin. There was a sense of porosity between Ben's body and the matter that surrounded it, of the cocomposition of himself and the elements in which he was immersed. Sturken (2016: 16) identifies the peculiar qualities of dust in her research on the $9 / 11$ museum in New York City, arguing that 'dust makes visible the continual material existence of substances of the past - a 'not-going-awayness'. She argues that dust is a transformed material form that carries the past with it, literally into the bodies of people who encounter it. Furthermore, Ben's account also showed how such an experience can include and engender memory and imagination. The materiality of the room and his sensory apprehension of it worked to fold time and memory into multiple intersections that overall prompted a fecund and powerful encounter.

Several different periods of the site's history are marked in the material and sensory environment through its different areas. This occurs explicitly through the presentation of its use from 1937 to 1942 in the museum displays and information panels, and is also evident in the retention of industrial fittings and implements and in the accreted grime that appears more recent. As one walks to the entrance of the main building from the car park, unused tiles are stacked in the adjoining yard, presumably for use for on-site repairs, and these recall the function of the factory that had closed only in the early 1990s. One can easily imagine the presence of internees, and this is actively encouraged through text, photographs, and the retention of graffiti and other markings. But the former factory workers are also readily imaginable, even if their activities and experiences of the building were 
drastically different from people imprisoned there. Thus, the lives of very different workers and inhabitants in time are present in the contemporary layering of dust, artful dilapidation, contemporary renovation and museum fixtures. Ben responded to this with his own memories of an industrial setting, albeit with emotional associations that are positive and even pleasant.

As he described, one effect of the material and spatial aspects of the site is to call to mind previous workers or inhabitants of the building, as one imagines other bodies experiencing the same temperature changes and dusty, still air, or speculating on the use of unfamiliar industrial implements. This is an aspect of how Edensor (2005a: 842) draws together matter and the embedded work of those who fashioned, manipulated or managed it, through his work on industrial ruins. He describes such abandoned places as:

an intersection of the visible and the invisible, for the people who managed them, worked in them, and inhabited them are not there. And yet their absence manifests itself as a presence through the shreds and silent things that remain, in the objects we half recognise or surround with imaginings.

In the case of Camp des Milles, however, the presence of previous inhabitants or workers is not left entirely to the imagination. The displays explaining camp life, artworks created by internees and testimonies of survivors all lead visitors to particular ways of visualizing it, particularly in the 1939-42 period. While the built 
environment and material objects invoke absent people and long-past activities, the museum displays represent these thoroughly and organize them as an official archive. For this reason, the layering of Ben's personal memories, and their multichronological nature, introduce a more intimate and visceral quality to the site, one that is at once in the 'minor key' (Manning 2016) and powerfully affecting.

At the same time that it may appear ruined or crumbling, however, the memorial section of Camp des Milles has been carefully designed and meticulously maintained. Indeed, the site underwent a long development process that saw multiple design teams attempt to find the suitable balance between the 'artistic', the historical and the pedagogical, to capture a sense of the distressing and difficult experiences of people held there without repelling visitors from the environment in they occurred. Despite the personal and even intimate nature of Ben's story, it is important to recognize that Camp des Milles presents a very clear narrative about the Second World War that is deployed to overtly pedagogical ends. The last section of the museum reinforces this in is a text-rich area that links the Holocaust with previous and subsequent genocides in Armenia (1915) and Rwanda (1994). This area includes a multi-screen film that immerses the viewer in the audiovisual material and invites them to consider the steps by which societies can come to condone largescale killing. Visitors are also urged to imagine what they would have done to resist such large-scale, targeted violence and reminded that even small forms of resistance have social and personal validity. 
The route through the memorial section in the main factory building is also carefully choreographed. It shows visitors where internees slept, the scant toilet facilities and locations of paintings, signs and graffiti made by prisoners. The subtle but careful lighting of these features pull the eye towards them, and combined with the apparently deliberate placement of antiquated equipment and the unscrubbed patina on the structural surfaces, the hand and eye of the designer can be discerned. This demonstrates the complexity of such sites, the interwoven nature of the statesponsored and official with the intimate and personal; the appearance of decay or ruin and the artful curation and maintenance of those spatial qualities; and the layering of the sensory and experiential with the explicitly representational. As we discuss in the final section, this unveils a politics of state-sponsored memory sites in which sensory perception might open memory up to new, disruptive possibilities.

\section{Conclusions: possibility and the 'feel' of memory}

The materiality of Camp des Milles is attuned to a ruined aesthetic that buttresses the affecting official narrative about the people held there, an atmospheric politics of the aesthetic that recalls Rancière's 'distribution of the sensible'. As he argues, 'politics revolves around what is seen and what can be said about it, around who has the ability to see and the talent to speak, around the properties of spaces and the possibilities of time' (Rancière 2004: 13). In the case of the Camp des Milles (and indeed many other state-sponsored memory sites), the careful design, controlled narrative and purposeful aesthetics help shape both the messages of the site and the sensory terms in which they are apprehended. 
As we have argued, however, as visitors are immersed in such spaces, their own memories can intrude by way of the senses, introducing new temporal layers that can complicate and intensify the emerging experience. Insisting on the value of including memory in non-representational geographies, Jones (2011: 875) remarks that 'We are conglomerations of past everyday experiences, including their spatial textures and affective registers'. Here, memory's spatial and affective qualities shape how we understand and make sense of our surroundings, and memory is revealed as a quality of the ongoing present and contingent future as much as it is an aspect of the multifarious past. As we have shown, one implication is that personal memories can help to make state-sponsored memory sites more powerful, and we have described how this was triggered by sensory and atmospheric impressions that moved far beyond the representational nature of conventional museum or memorial displays.

In doing so, we have traced some of the connections between memory, materiality, and the 'minor gesture', to arrive at a way of conceptualizing the 'feel' of lieux de mémoire that attends to the experiential and emergent beyond the narrative and representational. With its location in 'the welling event', rather than the field of the representational, the minor gesture makes possible the 'articulation...of new modes of being' (Manning 2016: 7). This resonates with Nora's (1989) differentiation between memory - the lived experience of the past passed down in vernacular traditions - and history - the official and linear record of the past that overtakes memory as individual stories fade or die. Lieux de mémoire such as Camp des Milles 
are commonly understood as official sites that present the past in terms of history that 'binds itself strictly to temporal continuities, to progressions and to relations between things' (Nora 1989: 9). Nora's seminal definition of such places locates them at a moment in which vernacular memory, reinforced and reiterated through the ongoing, repetitive patterns of lived experience, has been fatally eroded:

Lieux de mémoire originate with the sense that there is no spontaneous memory, that we must deliberately create archives, maintain anniversaries, organize celebrations...because such activities no longer occur naturally. (Nora 1989: 12)

Our research goes beyond this, however, by allowing us to attend to spaces of the past in a way that moves beyond the two poles of memory and history. Indeed, our research participants showed how spontaneous memory does emerge in officially organized sites, and furthermore that these exceed and complicate the chronological progressions represented in them.

Accordingly, we argue that a better understanding of the political heft and potential of memory sites can come into focus by attending to the minor, by rehabilitating the emergent, and from an understanding of the concomitant subtle and unpredictable slippage of multiple pasts into the perception and experience of the present. We also contend that the embodied experiences that visitors have in such sites remain vitally important in communicating about the past - that matter matters, and should not be abandoned or neglected in favour of virtual or digital replacements. In this 
sense, the actual places and objects of memory are irreplaceable in forging the affective encounters that not only allow memory to perdure, but also to connect feeling to narrative. Prompted by the senses, and by the material environments that nudge them into being, intimate memories return, the past becomes imaginable through the perceptions and feelings (including those of invisible others), and empathy and other affective intensities can be both fostered and turned to political and official ends. Edensor's (2005b: 145) work on industrial ruins expresses this sense of destabilizing possibility, the unexpected nature of involuntary memories and the powerful and unpredictable charge they carry:

The anarchic intrusions of involuntary memory act to destabilize that which has been recorded and classified as significant, and therefore worthy of remembrance. The variegated atmospheres, aggregations, textures, sounds and smells of ruin mean they are places in which to remember otherwise, realms rich in potential for the evocation of involuntary memories.

Ultimately, our account of the feel of memory, in both the haptic and affective sense, hinges on the potential the minor gesture offers to disrupt or recraft the official as represented in state-sponsored memory sites by way of how they are experienced. This includes the involuntary but powerful emergence of the past into the present. Manning (2016: 24 ) celebrates this as a generative quality of the minor gesture, insisting it is 'defined by its capacity to vary, not to hold, not to contain'. It opens possibility, allows us to think differently, to make time slippery and memory 
multi-chronological, and to thereby intensify experience and enrich meaning.

Entangled with the affective, it represents potential. It thus undermines singular narrative and official historical representation and is vital in making possible new ways of thinking about the past as multiply layered, and our individual and collective relationship to it, by way of how memory feels and the environments which make these feelings possible.

\section{References}

Anderson, B (2009) Affective atmospheres. Emotion, Space and Society 2: 77-81.

Bennett, J (2010) Vibrant Matter: a political ecology of things. Raleigh, NC: Duke University Press.

Camp des Milles, http://www.campdesmilles.org/. Accessed 10 January 2017.

Camp des Milles (n.d.), 'Les Milles Camp Memorial Site (visitor guide)'. Foundation of the Camp des Milles - Memory and Education.

Connerton, P (1989) How Societies Remember. Cambridge: Cambridge Univeristy Press.

Coole, D and Frost, S (2010) New Materialisms: Ontology, Agency, and Politics. 
Durham: Duke University Press.

Crouch, D (2015) 'Affect, Heritage, Feeling' in Waterton, E and Watson, S (eds) The

Palgrave Handbook of Contemporary Heritage Research. Abingdon: Palgrave: 177-

190.

Drozdzewski, D (2014) When the Everyday and the Sacred Collide: Positioning

Płaszów in the Kraków Landscape', Landscape Research 39(3): 255-266.

Drozdzewski, D, De Nardi, S and Waterton, E (2016a) ‘Geographies of memory, place and identity: Intersections in remembering war and conflict', Geography Compass 10 (11): 447-456.

Drozdzewski, D, De Nardi, S and Waterton, E (eds) (2016b) Memory, Place and Identity: Commemoration and remembrance of war and conflict. Abingdon: Routledge.

Edensor, T (2005a) 'The ghosts of industrial ruins: ordering and disordering memory in excessive space', Environment and Planning D: Society and Space 23: 829-849.

Edensor, T (2005b) Industrial Ruins: Space, Aesthetics and Materiality. Oxford: Berg.

Edensor, T (2012) 'Illuminated atmospheres: anticipating and reproducing the flow of affective experience in Blackpool', Environment and Planning D: Society and Space 
30: $1103-1122$.

Edensor, T and Sumartojo, S (2015) 'Introduction: Designing Atmospheres', Visual Communication 14(2): 251-266.

Freeman, L, Nienass, B and Daniell, R (2016) 'Memory, Materiality, Sensuality', Memory Studies 9 (1): 3-12.

Gillis, J (1994) 'Memory and Identity: the History of a Relationship' in John R. Gillis ed, Commemorations. The Politics of National Identity. Princeton, NJ: Princeton University Press.

Halilovich, H (2016) 'Re-imaging and re-imagining the past after 'memoricide': intimate archives as inscribed memories of the missing', Archival Science 16: 77.

Ingold, T (2011) The Perception of the Environment: Essays on Livelihood, Dwelling and Skill. Abingdon: Routledge.

Jones, O (2011) ‘Geography, Memory and Non-Representational Geographies’. Geography Compass 5 (12): 875-885.

Jones, $\mathrm{O}$ and Garde-Hansen, J (eds) (2012) Geography and Memory: Explorations in Identity, Place and Becoming. Basingstoke: Palgrave. 
Manning, E (2016) The Minor Gesture. Durham: Duke University Press.

McCormack, D (2008) ‘Engineering affective atmospheres on the moving geographies of the 1897 Andrée Expedition', cultural geographies 15: 413-430.

Muzaini, H (2015) 'On the matter of forgetting and "memory returns"', Transactions of the Institute of British Geographers 40: 102-112.

Nora, P (1989) 'Between Memory and History: Les Lieux de Mémoire'.

Representations 26: 7-24.

Pérez-Gómez, A (2016) Attunement: Architectural Meaning After the Crisis of Modern Science. Cambridge, Mass: MIT Press.

Pink, S (2007) 'Walking with video', Visual Studies 22(3): 240-252.

Pink, S (2015) Doing Sensory Ethnography. London: Sage

Pink, S, Sumartojo, S, Lupton, D and Labond, C (2016) 'Mundane Data: the routines, contingencies and accomplishments of digital living', Big Data and Society. DOI:

$10.1177 / 2053951717700924$

Rancière, J (2004) The Politics of Aesthetics (trans. by Rockhill, G) London: Continuum. 
Sather-Wagstaff, J (2017) 'Making polysense of the world: affect, memory, heritage' in Tolia-Kelly, D, Waterton, E and Watson, S (eds) Heritage, Affect and Emotion:

Politics, practices and infrastructures. London: Routledge: 12-30.

Stewart, K (2007) Ordinary Affects. Durham: Duke University Press.

Sturken, M (2016) 'The objects that lived: The 9/11 Museum and material transformation', Memory Studies 9(1): 13-26.

Sumartojo, S (2015) On atmosphere and darkness at Australia's Anzac Day Dawn Service', Visual Communication 14(2): 267-288.

Sumartojo, S (2016) 'Commemorative atmospheres: memorial sites, collective events and the experience of national identity', Transactions of the Institute of British Geographers 41(4): 541-553.

Waterton, E and Dittmer, J (2014) 'The museum as assemblage: bringing forth affect at the Australian War Memorial', Museum Management and Curatorship 29(2): 122139.

Witcomb, A (2013) 'Understanding the role of affect in producing a critical pedagogy for history museums', Museum Management and Curatorship 28(3): 255-271. 
Zumthor, P (2006) Atmospheres. Basel: Birkhäuser. 


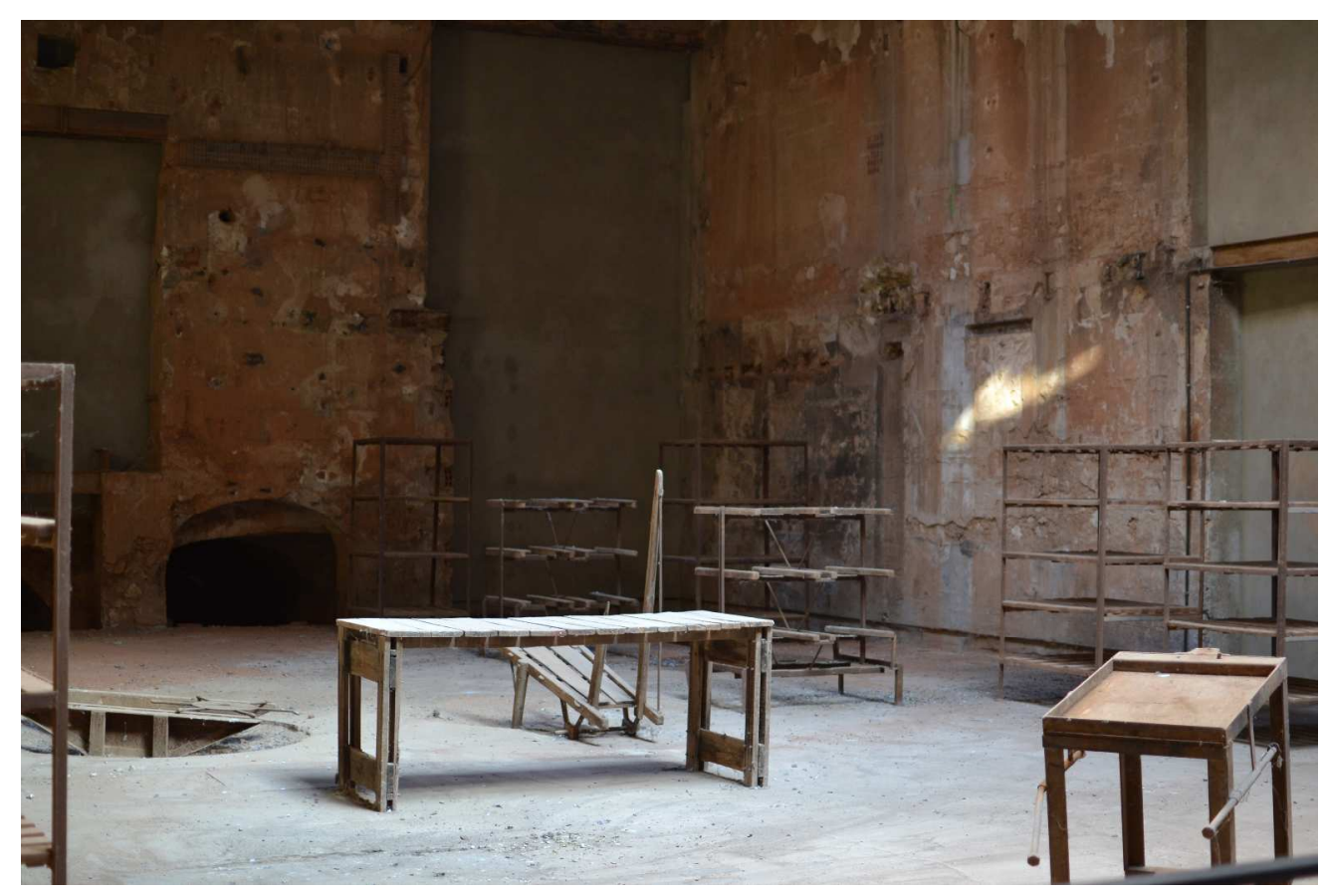

Figures 1-4: The main room in the memorial section of Camp des Milles. Photos: xxx. $390 \times 260 \mathrm{~mm}(300 \times 300 \mathrm{DPI})$ 


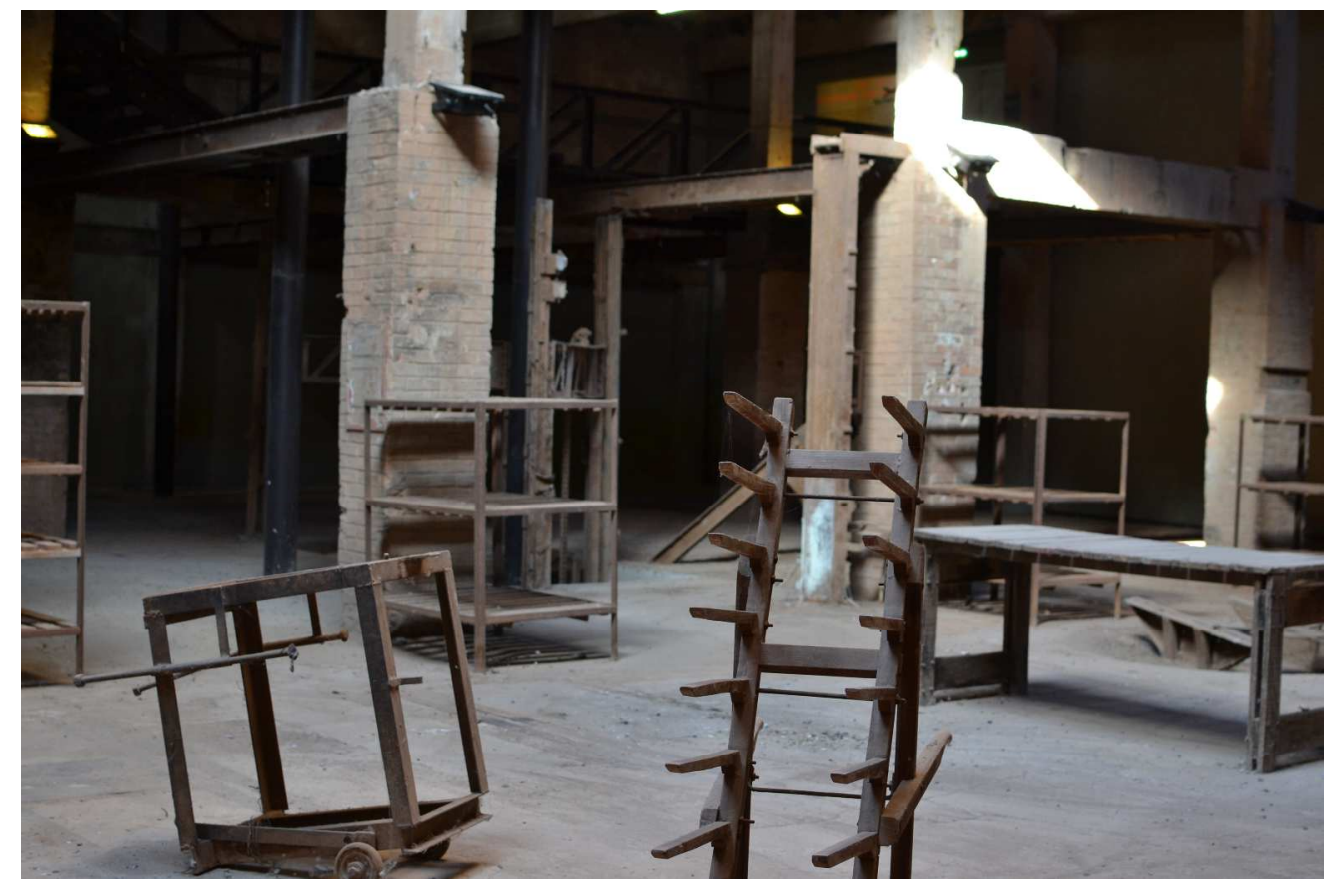

$390 \times 260 \mathrm{~mm}(300 \times 300 \mathrm{DPI})$ 


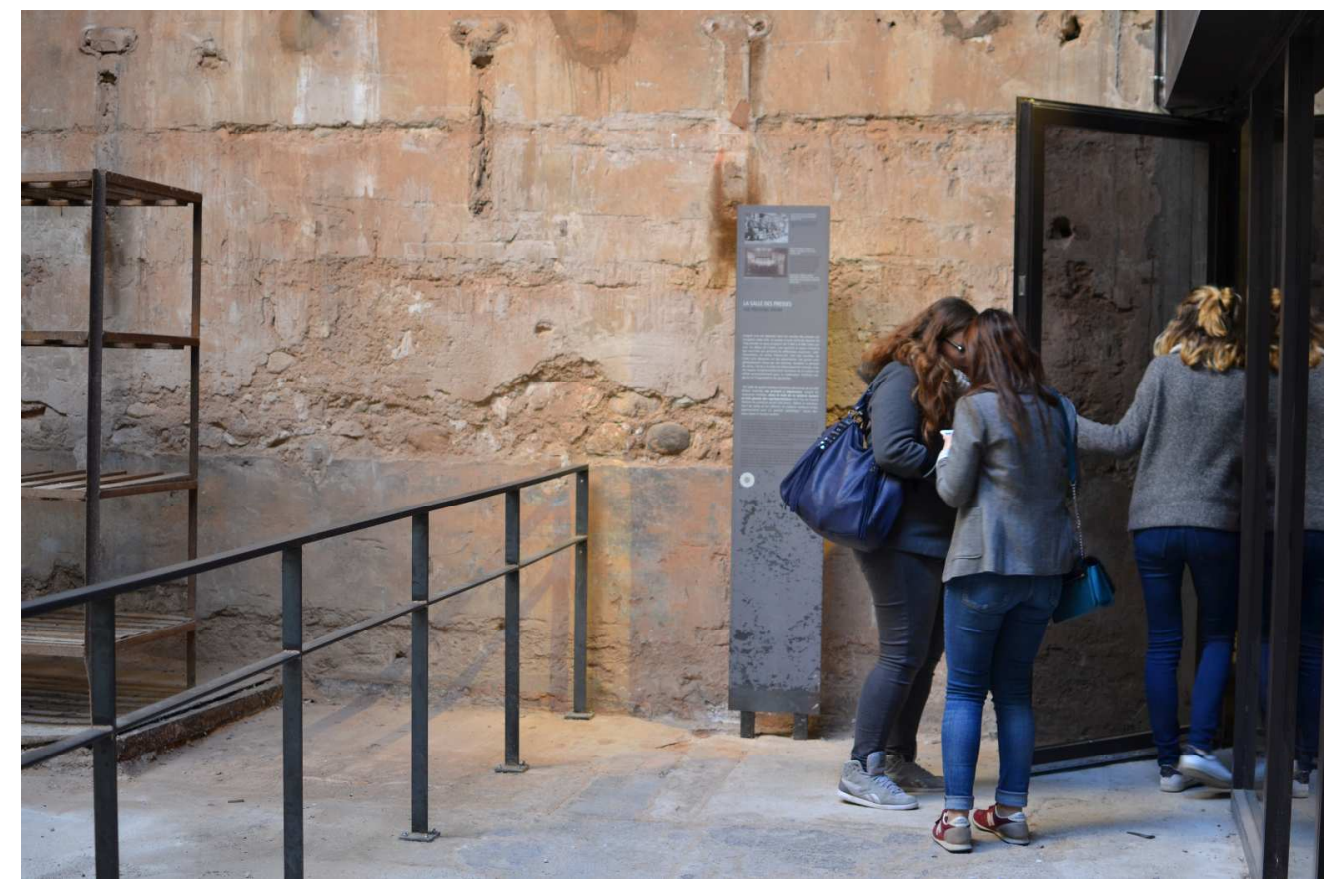

$390 \times 260 \mathrm{~mm}(300 \times 300 \mathrm{DPI})$ 


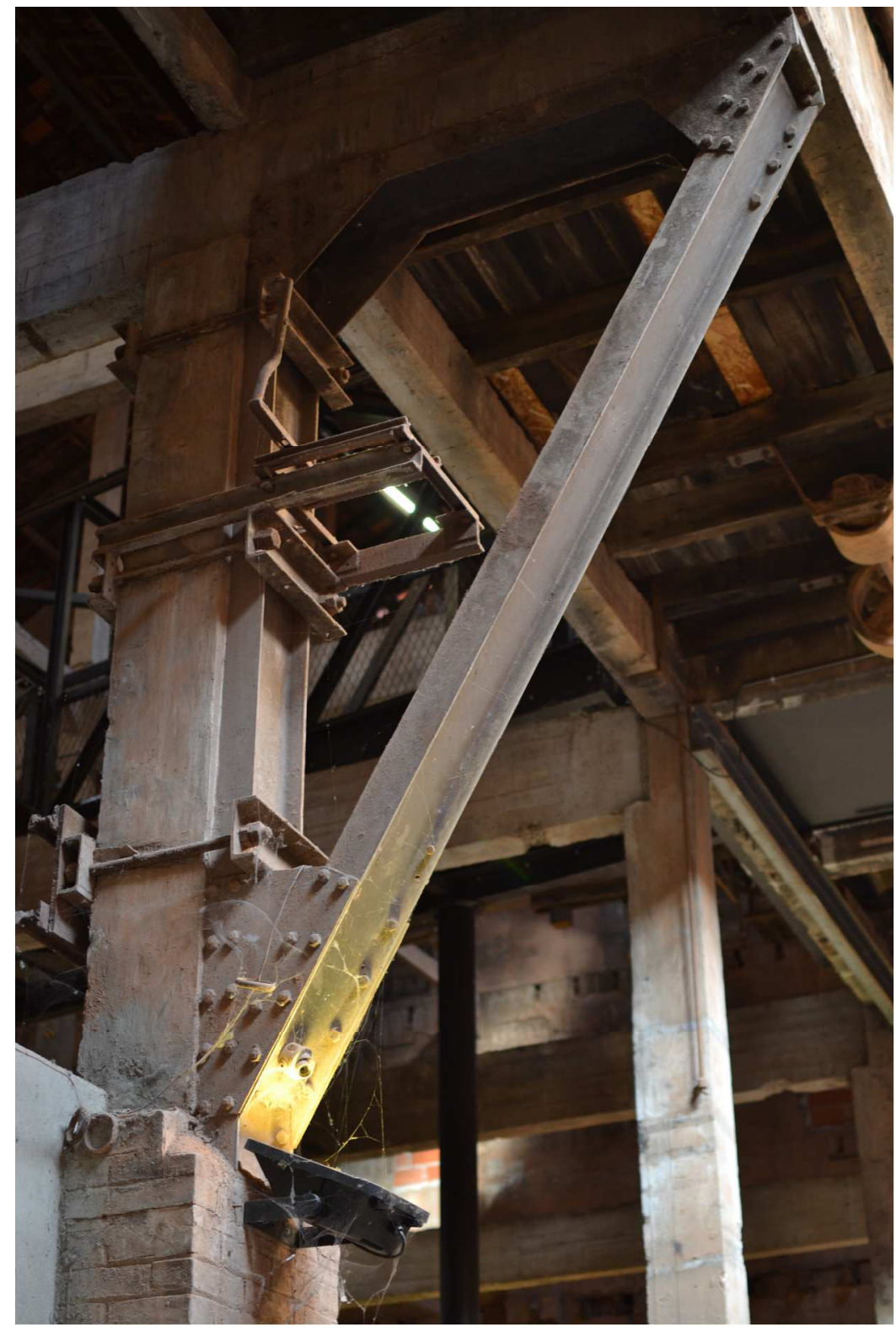

$260 \times 390 \mathrm{~mm}(300 \times 300 \mathrm{DPI})$ 


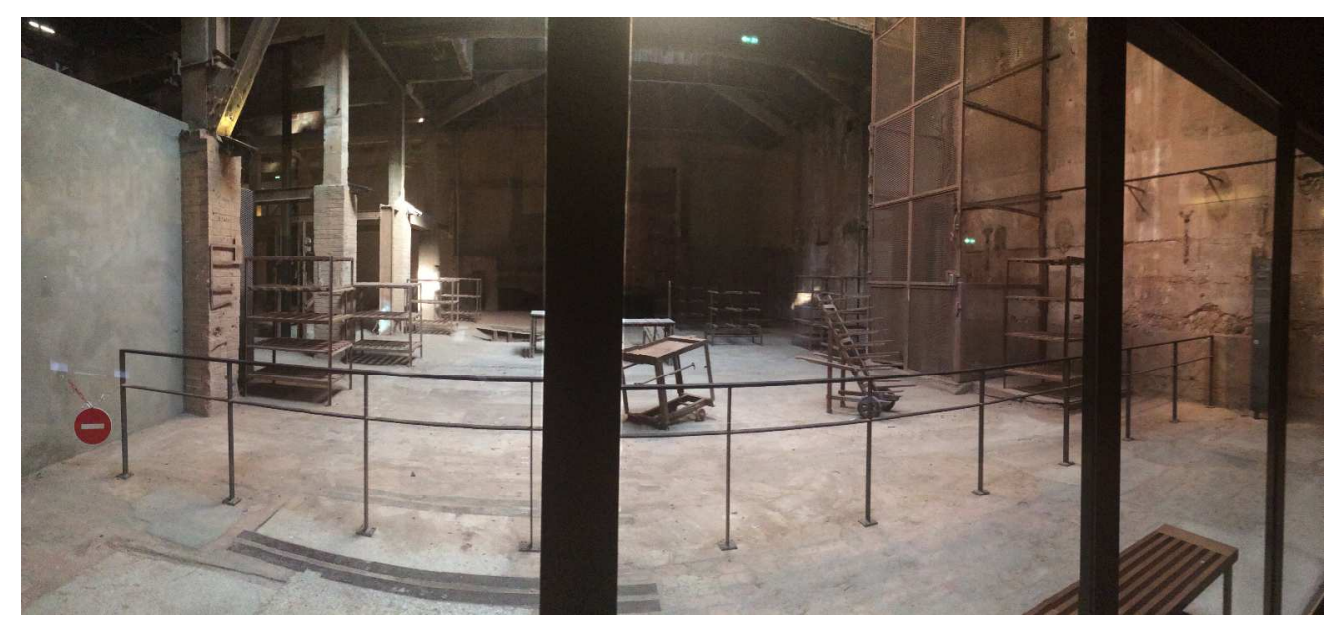

Figure 5: B's panorama image of the same room.

$1921 \times 881 \mathrm{~mm}(72 \times 72 \mathrm{DPI})$ 


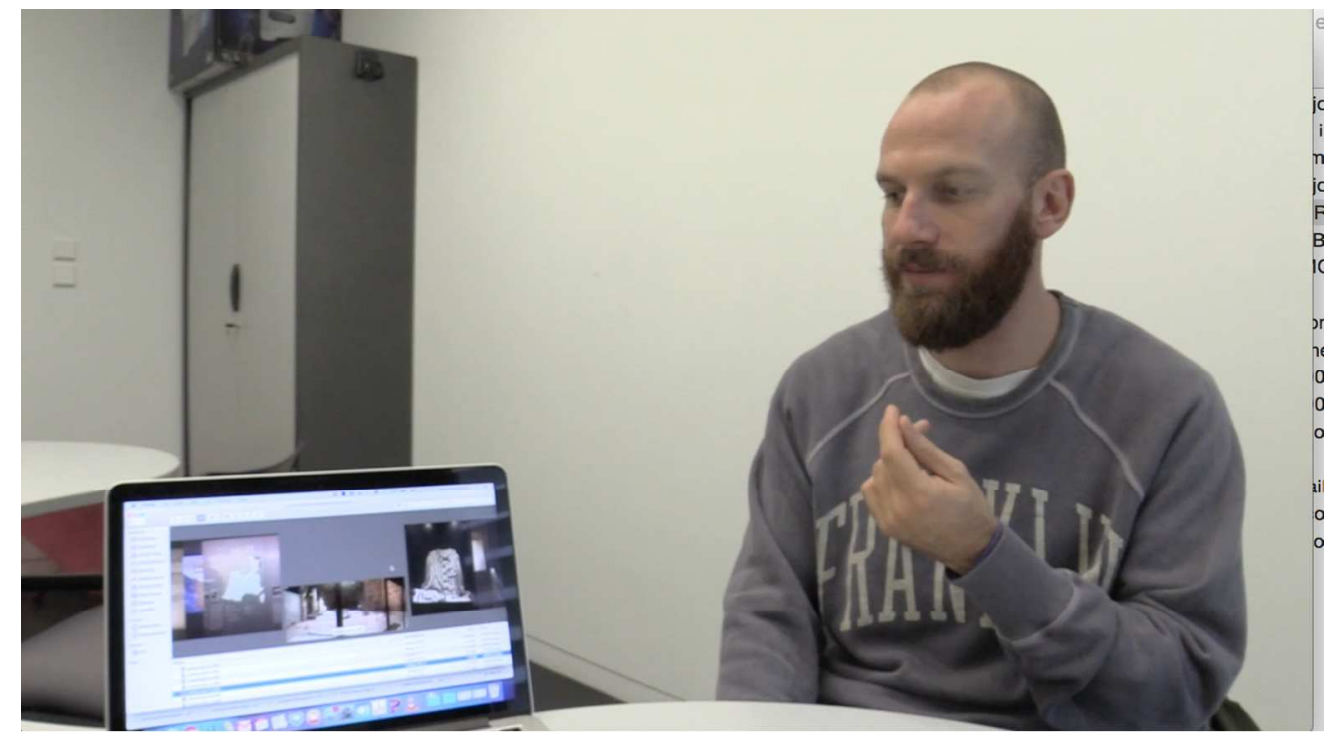

Figure 6: A still from xxx's interview with B, when he described the smell and feel of the dust he sensed in the room in his photograph by rubbing his fingers and thumb together. He is glancing at the photograph of the room on the computer screen. 